\title{
Corruption, human rights and extraterritorial obligations
}

\author{
Khulekani Moyo
}

\section{Introduction}

Corruption is one of the greatest evils in the fight to eradicate poverty and in ensuring a dignified living for all people. Corruption has long been recognised as a potentially serious problem in every polity and an impediment to economic development especially in less developed countries (Krever 2007). Corruption impedes the fight against poverty as it increases the cost-ofservice delivery through theft and misallocation of resources meant for the provision of public goods. Much of the literature on the causes and consequences of corruption, however, often focus on the demand side - the officials who accept corrupt payments in exchange for favour and influence (Krever 2007). Slowly, however, the impetus has begun to shift towards focusing on the supply side of corruption. Some powerful multinational corporations (MNCs) based in the global north are more often than not identified as common culprits of supply-side corruption and in the process giving corruption a transnational character calling for global solutions (Krever 2007).

Corruption is also closely linked to severe loss of potential public revenue due to illicit financial flows. According to the High-Level Panel on Illicit Financial Flows from Africa, the continent loses over 88.6 billion dollars annually due to illicit financial flows (United Nations Conference on Trade and Development (UNCTAD) 2020). It is not surprising then that Sustainable Development Goals (SDGs) include targets such as the reduction of corruption and bribery in all their forms (UN 2015). The realisation of the SDGs is to a considerable extent predicated on transparency, participation, accountability - values that are important for an anticorruption drive.

There is little doubt that corruption is one of the biggest obstacles for an effective implementation of economic, social and cultural rights as well as civil and political rights. Corruption is an impediment not only for the realisation of human rights but also for development in general. The diversion and siphoning off of public resources as a result of endemic corruption impacts heavily on the marginalised members of the community and denudes them of their dignity. At the very least, corruption compromises a state's capacity to deliver public services, particularly socio-economic goods such as water, housing, sanitation, healthcare and education. 
Increasingly, there is a realisation in the interconnected nature of the world. Whether it is the coronavirus pandemic or terrorist attacks, events occurring in one part of the world have impact on the other corner of the globe. In addressing such impacts, coordinated global responses are required for any meaningful impact.

The incidence of corruption, given its transnational character, has the capacity to engage state responsibility under international law where a state fails to prevent or regulate actors from its territory from engaging in corrupt activities which have deleterious acts on the enjoyment of human rights abroad. The Committee on Economic, Social and Cultural Rights (CESCR 2017, para. 28) has explained that:

Extraterritorial obligations arise when a state party may influence situations located outside its territory, consistent with the limits imposed by international law, by controlling the activities of corporations domiciled in its territory and/or under its jurisdiction, and thus may contribute to the effective enjoyment of economic, social and cultural rights outside its national territory.

The CESCR in its General Comment no. 24 (2017, para. 20) has further noted that 'Corruption constitutes one of the major obstacles to the effective promotion and protection of human rights, particularly as regards the activities of businesses'. The Maastricht Principles on Extraterritorial Obligations of states in the Area of Economic, Social and Cultural Rights (Maastricht Principles 2011) are particularly illuminating by their clarification that a state has obligations not only to desist from infringing on the human rights of those beyond its territorial limits, but also to regulate individuals and entities within its jurisdiction from perpetrating acts of corruption and bribery abroad. According to the Maastricht Principles, the extraterritorial obligation to respect requires states to refrain from interfering directly or indirectly with the enjoyment of rights by persons outside their territories (Principle 29). It is also noteworthy that under international law, a state may incur responsibility for human rights violations when any entity, such as a business enterprise, which they have obligations to regulate engage in acts or omissions resulting in human rights violations abroad. This obligation is also addressed in the Maastricht Principles. An extraterritorial obligation to protect requires states to take steps to prevent and redress infringements of rights that occur outside their territories due to the activities of business entities over which they can exercise control (Principle 30). The obligation to protect with respect to extraterritorial obligations thus enjoins a duty on the state to regulate the conduct of non-state actors, over which a state has regulatory authority.

Corruption is a particularly insidious phenomenon, which stifles economic development, has devastating effects on the most vulnerable members of society, both in developing and developed nations. As noted by Cleveland et al. (2009), there is a universal disdain for corruption that transcends borders, cultures and ideology and this has provided a global impetus and vigour to curb the corruption plague. It is against this background that both practice and scholarship have increasingly courted a human rights-based approach in the fight against the scourge of corruption (Peters 2018). Anti-corruption and anti-bribery are among issues that states have recognised a regulatory role with respect to extraterritorial acts of their natural and legal persons. States have adopted domestic legislation designating bribery and corruption abroad as offences. In addition, states have adopted a number of international and regional anti-corruption conventions to address the scourge of corruption. This chapter explores the developments on ETOs in the anti-corruption/anti-bribery field. It also engages with human rights ETOs around anticorruption and links them with debates on the fulfilment of state human rights obligations. This chapter is divided into four parts. The first part defines corruption, followed by a discussion of 
international law's response to corruption, highlighting the extraterritorial dimension of the response against corruption. The United States' (US) domestic legislation is also discussed given its importance in the development and growth of the international, regional and comparative legal regimes aimed at addressing corruption. The third part evaluates the legal question on whether corruption should be regarded as human rights violations. This part thus examines how re-framing corruption as a rights violation has important normative implications and could improve enforcement measures against acts of corruption and bribery at both national and international levels. In that regards, the part seeks to address whether corruption can and should be conceptualised as a violation of human rights engaging state responsibility where individuals or groups living are denied access to public goods they are entitled to as a result of corruption and acts of bribery by using social and economic rights to illustrate on how corruption can violate human rights, followed by the conclusion.

\section{Definition of corruption}

The most common definition of corruption is by Transparency International, which defines corruption as the abuse of entrusted power for private gain (Moyo 2017). The United Nations (UN) and African Union (AU) conventions adopted to address corruption and related issues do not provide a precise definition of corruption, but rather stipulate a range of corrupt practices that must be criminalised under national laws. The UN Convention Against Corruption (2003), for instance, criminalises corrupt practices such as bribery, money laundering, abuse of power, embezzlement and trading in influence. Similarly, the AU Convention on Preventing and Combating Corruption (2003) criminalises a wide range of acts, including domestic and foreign bribery, illicit enrichment, money laundering and concealment of property. The common denominator of such corrupt practices is that they consist of inducing undue advantage from public officials and private entities for personal gain. The Southern African Development Community Protocol against Corruption (2001) defines corruption as 'includ[ing] bribery or any other behaviour in relation to persons entrusted with responsibilities in the public and private sectors which violates their duties as public officials, private employees, independent agents or other relationships of that kind and aimed at obtaining undue advantage of any kind for themselves or others' (art. 1).

Corruption may happen on the level of day-to-day administration and public service referred to as petty corruption or at the high level of political office referred to as grand corruption (Shah and Schacter 2004). Corrupt practices include bribery, nepotism, theft and other abuses of public power for private benefit (Ünver and Koyuncu 2016). Corruption, by its nature, uses state resources and institutions to purloin, embezzle or enrich those in public office at the expense of the state's wealth and its citizens' welfare.

The literature generally emphasises corruption in the public sector, even though the private sector is a prominent player in the corruption stakes (United Nations Economic Commission for Africa (UNECA) 2015). The narrow notion of understanding corruption as the 'abuse of public office for private gain' should be challenged. Such an understanding of corruption neglects the corrupt tendencies that are rampant in the private sphere. Corruption can and does occur between firms and individuals or between actors in the private sector and the public sector, for example, through state capture, where private entities 'capture' state institutions for their own benefit (UNECA 2015). It is imperative to understand the importance and implications of viewing corruption as a broader phenomenon where non-state actors share a significant responsibility for engaging and aiding corruption as captured in the SADC Protocol's definition of corruption. 


\section{Corruption and human rights - the gap}

Although corrupt conduct undoubtedly impedes the realisation of human rights, international and regional human rights instruments make no direct mention of corruption. Furthermore, the human rights treaty monitoring bodies have failed to bring conceptual clarity to the question of how corruption can potentially be construed as a human rights violation. Thus, as a language for describing the harms caused by corruption, international human rights law lacks explicit legal provisions or helpful guidance by treaty monitoring bodies. Moreover, the state-centred character of human rights law reduces its usefulness with respect to corruption, an insidious practice that often takes place at the intersection of the public and private sectors (Rose 2016). Fundamentally, the state-centric nature of human rights law limits its capacity to address such conduct as corruption is not limited to public actors but also permeates the private sector. The relationship between corruption and human rights is addressed in the part below. The next section discusses some of the international law responses to the corruption phenomenon, as well as the importance of an extraterritorial approach to addressing this scourge.

\section{International law's response to corruption}

Apart from being the target of transnational norms, corruption and other undesirable transnational activities such as human trafficking have been increasingly subject to national norms of municipal regulation with extraterritorial effect. This has resulted in the extraterritorial application and enforcement of national laws to subjects acting beyond the borders of a given country. The increasing international and national recognition of rights that protect interests closely related to poverty such as the rights to adequate healthcare, sufficient and safe water and sanitation, education, housing and food has begun to change the landscape in the fight against corruption. The period from the early 1990s saw the adoption of global and regional treaties aimed at addressing and curbing the scourge of corruption. Their emergence in the 1990s, in turn, was a reaction to the globalisation of corruption itself, an acknowledgement that corruption had acquired transboundary elements.

Consequently, there is a growing tendency to criminalise and prosecute corruption in its various manifestations such as bribery, both internationally and domestically. What is discernible is the shift from where corruption beyond the borders of a nation state was not regulated at all (before 1977), through one where only the United States (US) formally prohibited foreign bribery (1977-1998), to the current state of affairs where a considerable number of international, regional and national normative standards have been adopted to address corruption. This section discusses some of the international norms, albeit briefly, that aim to address corruption in its extraterritorial manifestations. Given its importance in driving the impetus in the adoption of international norms, the US' Foreign Corrupt Practices Act of 1977 (FCPA 1977), although national legislation, is the subject of this discussion given its importance in the emergence and development of international, regional and domestic anti-corruption norms.

\section{Foreign Corrupt Practices Act}

The adoption of the first comprehensive set of domestic norms on transnational bribery goes back to 1977, when the US adopted the FCPA. In that regard, the US was the first country to prohibit payments to foreign government officials to secure a business advantage (Searle Civil Justice Institute 2012). Investigations by the US Congress in the mid-70s revealed that many US corporations were making payments to foreign government officials to obtain business. 
Simultaneous investigations surrounding the Watergate scandal revealed that many US firms maintained slush funds to bribe foreign and domestic political officials. These revelations led the US Congress to adopt the FCPA, making the US the global pioneer to enact a law that criminalises acts of corruption in transnational business transactions (Searle Civil Justice Institute 2012).

The FCPA's anti-corruption provisions are thus implicated when engaging in transnational business. The FCPA (1977) criminalises the provision of anything of value to a foreign official for the purposes of securing any improper business advantage. The FCPA thus exclusively focuses on the supply side of the corruption transaction (FCPA 1977, para. 78dd-1(a)). Furthermore, the FCPA only addresses public corruption in the context of international business, and proscribes corrupt acts that are provided to foreign public officials. Significantly, the FCPA is unique because of its jurisdictional provisions that provide a state with extraterritorial enforcement jurisdiction to reach a wide range of domestic and foreign subjects. One may argue that such a broad construction of jurisdiction is desirable from the perspective of stamping out foreign corrupt practices as a global evil whose transnational tentacles require the exercise of extraterritorial jurisdiction.

There is little doubt that the internationalisation of the anti-corruption effort is key to bolstering anti-corruption efforts (Krever 2007). The FCPA provided the impetus and raised the public profile of corruption, both domestically in the US and internationally, thereby paving the way for the adoption of international, regional and domestic norms meant to curb corruption. The FCPA has thus been responsible for increasing political pressure to pursue multilateral conventions on corruption and the increased international awareness has also encouraged many developing countries to join the bandwagon in addressing the demand side of bribery (Krever 2007). Ultimately, the FCPA became the model for similar international initiatives such as the Organisation for Economic Cooperation and Development's Convention on Combating Bribery of Foreign Public Officials in International Business Transactions (OECD Convention), which is discussed below.

\section{Inter-American Convention Against Corruption}

Another particularly watershed international development was the decision of the Organization of American States (OAS) to address corruption and bribery. The OAS' Inter-American Convention Against Corruption, adopted in March 1996 (IACA), was the first binding international legal instrument to establish a comprehensive legal framework aimed at preventing and combating corruption. The IACA, which has been ratified by 34 states from the Americas, has particular significance in that it marked the beginning of an international legal regime to combat corruption by criminalising domestic and transnational bribery. The OAS' adoption of IACA thus ranks among the first efforts, outside of the US, to codify extraterritorial efforts to fight corruption.

The IACA (art. 11.1) emphasises as one of its purposes to "promote, facilitate and regulate co-operation among States Parties to ensure the effectiveness of measures and actions to prevent, detect, punish and eradicate corruption in the performance of public functions and acts of corruption'. A particularly noteworthy feature of the IACA is that amongst the proscribed conduct, it includes corrupt activities of both public officials and foreign public officials, and such a provision empowers member states to exercise both prescriptive and enforcement extraterritorial jurisdiction to prevent and curb corruption. In that regard, the IACAC has an extraterritorial dimension and makes active bribery of a foreign public official an offence (art.VIII). The IACAC extends criminal jurisdiction based on territoriality and nationality principles 
(art.V). Importantly, state parties are required to extend jurisdiction to offences committed by their nationals or residents, even if they were not committed inside their territory (art. 5, para. 2), thereby magnifying the extraterritorial character of the IACA is addressing transnational corruption.

\section{OECD Convention}

The process of moving from a unilateral American legislative initiative to an international anticorruption movement spanned more than 20 years. Another important international development relating to corruption was the adoption of the OECD Convention in 1997. The OECD Convention's primary objective goal was to eliminate the unfair competitive advantages obtained by corporations paying bribes in foreign markets. The OECD Convention was thus seen as a landmark in combating international corruption by requiring legislative convergence on the addressing transnational corruption. Its significance is that it was the first international attempt by the major capital-exporting countries to curb the 'supply side' of corruption, that is, the willingness of MNCs from the global north to bribe foreign public officials (Kaczmarek and Newman 2011). To achieve this goal, the OECD enjoins its member states to enact legal and policy measures to prevent, detect, investigate, prosecute and sanction corruption of foreign public officials. In that regard, the OECD member states pledged to enact domestic legislation with extraterritorial effect in order to effectively regulate corporations domiciled in their jurisdictions when such corporations engaged in business activities abroad. Proponents of the OECD Convention suggest that it marks a revolution in the fight against corruption and is a significant component of the international legal regime to address transnational corruption in its various dimensions (Kaczmarek and Newman 2011).

At the core of the OECD Convention is Article 1, which elaborates the key elements constituting the offence of bribery of foreign public officials. Article 3 of the Convention states that member countries should criminalise the bribery of foreign public officials, stating that:

The bribery of a foreign public official shall be punishable by effective, proportionate and dissuasive criminal penalties. The range of penalties shall be comparable to that applicable to the bribery of the Party's own public officials and shall, in the case of natural persons, include deprivation of liberty sufficient to enable effective mutual legal assistance and extradition.

Additionally, Article 2 permits the exercise of extraterritorial jurisdiction by enjoining that every state party shall establish the liability of legal persons who bribe a foreign public official in accordance with national legal principles of each member state. Article 2 is thus important in its explicit authorisation of state parties to exercise both prescriptive and enforcement extraterritorial jurisdiction to prevent and punish corrupt acts occurring beyond a state's shores.

\section{UN Convention Against Corruption}

The key global anti-corruption instrument, the UN Convention Against Corruption (UNCAC), adopted in 2003, went beyond previous international agreements on corruption. It enjoins state parties to criminalise not only basic forms of corruption such as bribery and embezzlement of public funds but also trading in influence and concealment and laundering of the proceeds of corruption. Significantly, the high number of signatories and ratifications (187 currently) reflects the broad international consensus on the UNCAC. The UNCAC focuses on three major areas, 
namely prevention, criminalisation and enforcement against corruption and its various manifestations. The UNCAC requires states to introduce effective policies and institutional arrangements for the prevention of corruption, including the introduction of a specific anti-corruption body, codes of conduct and policies promoting good governance, the rule of law, transparency and accountability (UNCAC 2003).

The UNCAC (art. 5.4) enjoins states to collaborate with each other, and with relevant international and regional organisations, in promoting and developing the measures to prevent and combat corruption. Significantly, each state party is enjoined, within its domestic legal system, to identify, trace freeze, seize or confiscate proceeds of corruption (art. 31). Chapter IV of the UNCAC is exclusively devoted to international cooperation, setting forth detailed guidelines relating to extraditions, investigations, prosecutions and judicial legal proceedings. Article 42 UNCAC permits state parties to exercise jurisdiction over corruption on the basis of the normal principles of jurisdiction, namely nationality, territoriality and protection of state interests. Article 42 also contains a savings clause, which allows states to exercise other types of jurisdiction, provided that they are in keeping with international law. In that regard, Article 42 of the UNCAC is significant for its permissive approach to the exercise of jurisdiction to curb corruption, including the exercise of extraterritorial jurisdiction.

\section{Council of Europe's Criminal Law and Civil Law Conventions on Corruption}

The Council of Europe (CoE)'s Criminal Law Convention (Criminal Law Convention), adopted in 1999, covers both active and passive bribery (art. 2) of domestic and foreign public officials as well as a long list of other national and international bureaucrats (arts. 4-11). A pioneering feature of the Criminal Law Convention is that it extends criminal responsibility for bribery to the private sector, which is absent in some of the international anti-corruption instruments such as the OECD Convention. This reflects recognition of the need to emasculate any differences in the rules applicable to the private and public sector, which becomes especially important in view of the transfer of public functions to the private sector as a result of privatisation and public/ private partnerships.

Article 17 of the Criminal Law Convention, which provides for jurisdiction, establishes a series of criteria under which state parties can exercise enforcement jurisdiction over the criminal offences enumerated in Articles 2-14 of the Convention. Article 17 also provides for the principle of territoriality as a ground for the exercise of jurisdiction. What is clear is that it does not require that a corruption offence as a whole be committed exclusively on the territory of a state to enable it to exercise enforcement jurisdiction. If only parts of the offence were committed on its territory, a state may still exercise enforcement jurisdiction. In that regard, Article 17 permits the expansion of the principle of territoriality to encompass an extraterritorial dimension. Article 17 also sets out the principle of nationality as a ground for the exercise of jurisdiction. The nationality theory is also based upon the state sovereignty and provides that nationals of a state are obliged to comply with the domestic law even when they are outside its territory. It follows that if a national commits an offence abroad, then the state party is entitled to exercise jurisdiction in accordance with Article 17. Article 17 also provides for the exercise of jurisdiction based on the protection of the protection of the state or its interests. Article 17 is thus important to the extent that it provides a leeway for the state to exercise extraterritorial jurisdiction to investigate and punish acts of corruption, which is a significant provision to make the treaty more effective. Significantly, Article 25 enjoins states parties to cooperate with each 
other to the widest extent possible for the purposes of investigations and proceedings concerning criminal offences established in accordance with the Convention.

The CoE adopted the Civil Law Convention on Corruption in 1999 (Civil Law Convention). The Civil Law Convention provides for common international legal rules in the field of civil law and corruption (Council of Europe 1999). Importantly, the Civil Law Convention enjoins state parties to provide, in their domestic law, effective remedies for persons who have suffered damage as a result of acts of corruption, including the possibility of obtaining compensation for damage. The Civil Law Convention (art. 13) further provides for international cooperation by state parties in civil cases of corruption, including in obtaining evidence abroad, jurisdiction, recognition and enforcement of foreign judgments, thereby clothing the instrument with extraterritorial dimensions. In terms of Article 13, which provides for international cooperation, one of the guiding principles in the fight against corruption is an undertaking to develop international cooperation in all areas of the fight against corruption. This again provides the Civil Law Convention with an extraterritorial dimension in the fight against corruption and its various manifestations.

\section{The African Union Convention on Preventing and Combating Convention}

In 2003, the then-Organisation of African Unity, now the African Union, adopted the Convention on Preventing and Combating Corruption (AU Corruption Convention). The AU Corruption Convention also adds to a burgeoning series of international efforts to combat corruption through international law. The adoption of such international instruments is no doubt an acknowledgement of corruption and bribery's impacts on human welfare and the importance of a collective approach to address the scourge. Foremost among the AU Corruption Convention's objectives is promoting development by preventing, detecting and punishing acts of corruption on the African continent (art. 2).

The AU Corruption Convention mandates three essential steps: (1) prevention, (2) criminalisation and (3) international cooperation (art. 4-24) in addressing the domestic and international dimensions of corruption. The coverage of the AU Corruption Convention extends to public officials and to 'any other person', including members of the private sector (arts. 4 and 11) - an important provision to ensure that private sector corruption is also addressed. The AU Corruption Convention follows typical jurisdictional grounds for investigation and prosecution: the place of commission of the offence, the nationality and residence of the offender and the presence of the offender in a given territory (art.13(1)(a)-(c).) Significantly, the AU Corruption Convention subjects anyone who commits an act of corruption or its various manifestations such as bribery anywhere to the jurisdiction of the state party if the offence affects the state's vital interests (art. 13(a)-(d)). This clearly clothes member states with extraterritorial prescriptive and enforcement jurisdiction in the fight against corruption.

The international cooperation provisions in the AU Corruption Convention include extradition, tracing, seizure and confiscation of proceeds of corruption and mutual legal assistance (arts. 16-18). Most importantly, the AU Corruption Convention highlights the importance of eradicating corruption in development aid (art. 19(4)). It is, however, noteworthy that global instruments such as the UNCAC discussed above avoid taking a concrete position on the relationship between corruption and human rights. Such a pattern is also observable in the OECD Corruption Convention and other regional instruments discussed above where corruption and bribery are considered as crimes that undermine good governance and transparency and must be prevented, detected, punished and eradicated. In that regard, these instruments frame corruption 
as a means by which public goods that are fundamental for the realisation of human rights are negatively impacted by corruption but without explicitly characterising corruption as a direct human rights violation. The next section engages on the issue of whether corruption could be regarded as a human rights violation, in the process highlighting the significance of national and extraterritorial measures anchored in human rights to address the corruption scourge.

\section{Closing the gap}

A growing number of legal scholars and activists are pushing for a human rights approach to addressing corruption (Rose 2016). Some scholars have sought to base their arguments in existing international human rights instruments. Others have advocated for a human right to a corruption-free society (Boersma 2011). One proposal is that the fight against corruption could be advanced by framing it under a 'freedom from corruption' banner (Murray and Spalding 2015, p. 4). This would add a new and powerful dimension to the fight against corruption. Some scholars have argued that corruption could qualify as a crime against humanity (Kofeke-Kale 2000).

As discussed further below, the thrust of the argument to infuse human rights in the fight against corruption is that corruption has identifiable victims of human rights violations. The victim-oriented approach stemming from a human rights-based approach in the fight against corruption would complement the existing approaches to curb corruption. It is important to note that all human rights are endangered where corruption is endemic, and thus an approach predicated on human rights should be part of the arsenal in the fight against corruption (Ramasastry 2015). Despite the recognition that corruption undermines human rights values and norms, efforts to combat corruption in many countries do not include a human-rights perspective even though many of them have constitutions that contain bills or declarations of rights.

A critical legal question when drawing a nexus between corruption and human rights is whether corrupt acts could and should be regarded as human rights violations. The traditional approach is to view corruption as impacting the realisation of human rights but not itself constituting a human rights violation (Ramasastry 2015). However, attention is quickly shifting to cast a spotlight on the groups and individuals whose lives are negatively affected by rampant corruption.

The turn towards a human rights approach to corruption, which began in the late 1990s, appears to be motivated by a need to focus greater attention to the victims rather than solely on the perpetrators of such corrupt acts (Kofele-Kale 2015; Boersma 2012). The perpetrators of corruption are often the targets of international and regional treaties as well as domestic criminal laws that address corruption. Some commentators see human rights law as empowering for victims, though they have not elaborated on exactly how (Peters 2018). Others consider a human rights approach to be imperative given the inadequacies of anti-corruption norms and criminal law treaties in curbing corruption (Hatchard 2010). In that regard, a human rights lens provides a valuable normative framework to address corruption. The added value of elevating an issue to the level of a human right is that it establishes a universal norm that becomes more difficult to disregard. This approach also emphasises the duties of states, and in some cases non-state actors, as well as the rights of those negatively impacted by corruption. In that regard, the human rights framework helps to give a voice to those who otherwise are unable to assert their rights.

Acknowledging and deploying a human-rights lens in the fight against corruption would significantly strengthen the impetus to adopt preventative actions aimed at eradicating the scourge of corruption (Peters 2018). The human rights approach can explicitly highlight the deleterious effects of corruption, for example, the rights of persons denied access to safe drinking water, affordable housing and adequate healthcare due to misuse of public funds through 
corrupt activities. A human rights approach is also likely to engage state duties in the fight against corruption, and the possibility of engaging state responsibility for failing to protect the rights of those exposed to the damaging effects of corruption.

\section{An illustration on how corruption can violate social and economic rights}

It is noteworthy that corruption, by its nature, can impede the enjoyment of a very wide range of human rights, from civil, political, economic, social and cultural rights, to the rights of children, migrant workers and the disabled. It follows that, depending on the circumstances of a case, civil, political, economic, social and cultural rights can be violated by acts of corruption.

Under the ICESCR (art. 2), the obligation imposed on states is to 'take steps...to the maximum of its available resources, with a view to achieving progressively the full realisation of the rights recognised in the present Covenant by all appropriate means'. The human rights set out in the covenants, as well as the human rights contained in other international and regional instruments, as elaborated by the relevant treaty bodies, give rise to three kinds of duties, namely the duties to respect, protect and fulfil the protected rights.

The focus of this section is to illustrate the impact of corruption on the rights protected under the ICESCR because most, if not all, of the rights set forth in this instrument are commonly affected by all forms of corruption, be it petty or grand corruption. Considering the ICESCR is also important in that the instrument is the core international legal document on economic, social and cultural rights and affords protection to the most extensive range of these rights. These include the right to work, trade union rights, right to social security, rights to food, water, housing, the right to health and the right to education. The ICESCR therefore represents an important global instrument for evaluating the impact of corruption on the realisation of human rights.

Treaty monitoring bodies, courts and other tribunals have elaborated on the specific duties generated by human rights in the context of socio-economic rights as entailing the duties to respect, protect, promote and fulfil human rights (CESCR 2000; CESCR 2001; CESCR 2002). The duty to respect is essentially a negative obligation commanding the state to refrain from infringements that impede the enjoyment of rights. The duty to respect thus enjoins the state to desist from embarking on any measure that interferes with the individuals or groups' enjoyment of their rights (Chirwa 2004). The state is therefore required to refrain from obstructing or hindering the enjoyment of rights by adopting privatisation, trade or commercialisation policies that negatively interfere with the enjoyment of socio-economic rights (Moyo 2018).

The duty to protect primarily refers to protection from dangers emanating from third parties whose effect is to interfere with the enjoyment of human rights. While the duty to respect requires the state to abstain from deprivation of rights, the duty to protect enjoins the state to act positively to regulate, prevent and remedy rights breaches by non-state actors (Chirwa 2004). The duty to protect thus primarily imposes a positive obligation on the state to adopt the appropriate measures to protect rights holders from having their enjoyment of rights infringed by non-state actors.

The duty to fulfil requires the state to adopt appropriate legislative and other measures to ensure the full realisation of the right in question. The positive duty to fulfil is key to the enjoyment of socio-economic rights. The duties imposed by socio-economic rights enunciated above may become difficult to comply with in a climate characterised by corruption. A corrupt act may potentially violate each of these dimensions of state duties socio-economic rights impose on states. 
Peters (2018), for instance, has argued that socio-economic rights comprise the element of 'affordability' such as the affordability of essential medicine as a component of the human right to fulfil the right to health, the fact that corruption in procurement processes may make medicines more expensive could be seen as a human rights violation. In such a case, there is a clear and direct nexus between corruption and the violation of the right to health. This is particularly the case where a state fails to put in place effective anti-corruption measures or fails to investigate, prosecute or punish those implicated in acts of corruption.

The duty to protect against human rights violations by third parties is important in the fight against corruption. Failure by the state to adopt effective anti-corruption measures may incur state responsibility under the state's domestic and international human rights obligations, particularly under the ICESCR. The duty to protect under human rights law does not only require the state to protect those within its jurisdiction from the human rights violating actions of third parties. The state is also bound to prevent human rights risks in which public officials may be involved (Ebert and Sijniensky 2015), particularly where such public officials are involved in corrupt acts that are linked to the denial of the rights to certain sectors of the population.

A state taking seriously its duty to protect would strengthen its legislative, regulatory and other measures aimed at curbing corruption. In an environment plagued with rampant corruption, this would include the establishment of an effective and appropriately resourced anticorruption body. Related anti-corruption measures would include the enactment of codes of conduct for public officials in the execution of their public duties, strengthening of public procurement laws and regulations to curb malfeasance, and the adoption of norms and establishment of institutions to curb money laundering. The UN CESCR (2000) has emphasised the importance of states adopting effective measures to curb corruption. Within the context of the state's duty to fulfil, the UN CESCR, for instance, has identified misallocation of public resources resulting in the non-enjoyment of the right to health by individuals and groups, thereby impeding their enjoyment of that right (UN 2000). Where financial resources budgeted for the provision of healthcare services are corruptly misappropriated by government officials and thus resulting in the denial of healthcare services, the state might be held to be violating its duty to fulfil the right to adequate healthcare services (Peters 2018).

\section{Conclusion}

There is little doubt that corruption is one of the biggest obstacles for an effective implementation of economic, social and cultural rights as well as civil and political rights. Corruption is an impediment not only for the realisation of human rights but also for development in general. The diversion and siphoning off of public resources as a result of endemic corruption impacts heavily on the marginalised members of the community and denudes them of their dignity.

Anti-corruption and anti-bribery are among issues that states have recognised a regulatory role with respect to extraterritorial acts of their natural and legal persons. States have adopted domestic legislation designating bribery and corruption abroad as offences. In addition, states have adopted a number of international and regional anti-corruption conventions to address the scourge of corruption. This chapter explored the developments on ETOs in the anticorruption/anti-bribery field. It also engages with human rights ETOs around anti-corruption and links them with debates on the fulfilment of state human rights obligations.

This chapter has demonstrated that corruption is not only an insidious phenomenon which stifles economic development but also a human rights violation with identifiable victims. The Maastricht Principles are particularly noteworthy in plugging the regulatory gap by clarifying of states' obligations not only to desist from infringing on human rights of individuals and groups 
abroad but also to regulate individuals and entities within their jurisdiction from perpetrating acts of corruption and bribery abroad. Importantly, the extraterritorial obligation to respect human rights, according to the Maastricht Principles, requires states to refrain from interfering directly or indirectly with the enjoyment of human rights by persons outside their territories. In the same vein, an extraterritorial obligation to protect human rights requires states to take steps to prevent and redress infringements of human rights that occur outside their territories due to the activities of individual and entities over which they can exercise control.

Acknowledging and deploying a human rights lens in the fight against corruption would significantly strengthen the impetus to adopt preventative actions aimed at eradicating the scourge of corruption. The human rights approach can explicitly highlight the deleterious effects of corruption, for example, the rights of persons denied access to safe drinking water, affordable housing and adequate healthcare due to misuse of public funds through corrupt activities. A human rights approach is also likely to engage state duties in the fight against corruption, and the possibility of engaging state responsibility, including their extraterritorial obligations, for failing to protect the rights of those exposed to the damaging effects of corruption. Thus, reframing corruption as a rights violation has important normative and utilitarian implications, and could improve enforcement at both national and international levels.

\section{References}

African Union (2003) Convention on Preventing and Combating Corruption, 43 I.L.M. 1.

African Union/United Nations Economic Commission for Africa (UNECA) (2015) Report of the High Level Panel on Illicit Financial Flows from Africa.

Boersma, M. (2012) Corruption: A Violation of Human Rights and a Crime under International Law?, Intersentia. Chirwa, D.M. (2004) 'Water Privatisation and Socio-Economic Rights in South Africa', Law, Democracy and Development 4, 188-189.

Cleveland, $M$ et al. (2009) 'Sixth Annual Ethical Dimensions In Business: Reflections From The Business Academic Community', Journal of Business Ethics 90, 199-244.

Ebert, F.C. and Sijniensky, R.I. (2015) 'Preventing Violations of the Right to Life in the European and the Inter-American Human Rights Systems: From the Osman Test to a Coherent Doctrine on Risk Prevention?', Human Rights Law Review 15, 343-368.

Foreign Corrupt Practices Act (FCPA) (1977) as amended, 15 U.S.C.

Hatchard, J. (2010) 'Adopting a Human Rights Approach Towards Combating Corruption' in Boersma, M. and Hans Nelen, H. (eds). Corruption and Human Rights: Interdisciplinary Perspectives, Intersentia.

Inter-American Convention Against Corruption (1996) 35 I.L.M. 724, available at http:/www.oas.org/ juridico/english/Treaties/b-58.html.

Kaczmarek, S.C. and Newman,A.L. (2011) 'The Long Arm of the Law: Extraterritoriality and the National Implementation of Foreign Bribery Legislation', International Organization 65, 745-770.

Kofele-Kale, N. (2015) 'The Right to a Corruption-Free Society as an Individual and Collective Human Right: Elevating Official Corruption to a Crime under International Law', International Lawyer 34, 149-178.

Krever, T. (2007) 'Curbing Corruption - The Efficacy of the Foreign Corrupt Practice Act, 33 North', Carolina Journal of International Law \& Commercial Regulation 33, 83-102.

Lippitt, A.H. (2013) 'An Empirical Analysis Of The Foreign Corrupt Practices Act', Virginia Law Review 99, 1893-1930.

Moyo, K. (2017) 'An Analysis of the Impact of Corruption on the Realisation of the Right to Development' South African Journal on Human Rights 33, 193-213.

(2018) 'Taming the Leviathan: An Analysis of the Extraterritorial Application of the Right to Water under the African system for the Protection of Human Rights' in Chenwi, L. and Bulto, T. (eds). Justice Beyond Borders: The Extraterritorial Reach of African Human Rights Instruments, Intersentia. 


\section{Khulekani Moyo}

Murray, M. and Spalding, A. (2015) 'Freedom From corruption as a Human Right', 4 Brookings Institution, available at http://www.brookings.edu/research/papers/2015/01/27-freedom-corruptionhuman-right-murray-spalding.

Organisation for Economic Cooperation and Development (OECD) (1999) Convention on Combating Bribery of Foreign Public Officials in International Business Transactions.

Peters, A. (2018) 'Corruption as a Violation of International Human Rights', The European Journal of International Law 29, 1251-1287.

Ramasastry, A. (2015) 'Is There a Right to Be Free from Corruption?', University of California Davis Law Review 49(2), 703-739.

Raoul Wallenberg Institute (2017) 'Anti-Corruption And Human Rights - How to Become Mutually Reinforcing?' (13-14 November 2017) <https://rwi.lu.se/app/uploads/2018/02/Anti-Corruptionand-Human-Rights-RWI.pdf $>$ [accessed 24 January 2021].

Rose, C. (2016) 'The Limitations of a Human Rights Approach to Corruption', International and Comparative Law Quarterly 65, 405-438.

Searle Civil Justice Institute (2012) Preliminary Policy Report on the Foreign Corrupt Practices Act: An Empirical Examination Of Enforcement Trends, available at https://masonlec.org/site/rte_uploads/ files/FINAL\%20FCPA\%20REPORT\%20PDF.pdf.

Shah, A. and Schacter, M. (2004) 'Combating Corruption: Look Before you Leap', Finance and Development, available at https://www.imf.org/external/pubs/ft/fandd/2004/12/pdf/shah.pdf [accessed 24 January 2021].

United Nations Committee on Economic, Social and Cultural Rights (CESCR) (1999) GC 12 on the Right to Adequate Food, UN Doc E/C.12/1999/5.

(2000) GC 14 on the Right to the Highest Attainable Standard of Health,UN Doc E/C.12/2000/4. (2000) GC 14 on the Right to the Highest Attainable Standard of Health,UN Doc E/C.12/2000/4. (2002) GC 15 on the Right to Water, UN Doc E/C.12/2002/11.

United Nations Conference on Trade and Development (UNCTAD) (2020) Economic Development in Africa Report:Tackling Illicit Financial Flows for Sustainable Development in Africa.

United Nations Economic Commission for Africa (UNECA) (2016) Measuring Corruption in Africa:The International Dimension Matters - African Governance Report IV.

United Nations General Assembly (2003) United Nations Convention Against Corruption (UNCAC), U.N. GAOR, 58th Sess., U.N. Doc. A/RES/58/4.

(2015) Transforming our world: the 2030 Agenda for Sustainable Development, A/RES/70/1.

Ünver, M. and Koyuncu, J.C. (2016) 'The Impact of Poverty on Corruption', Journal of Economics Library $3,632-642$. 